\title{
Relationship between serum osmolality and intraocular pressure in normal and diseased eyes
}

\author{
B. M. MORE \\ Edinburgh Royal Infirmary
}

Patterns of diurnal change in blood osmolality and in intraocular pressure are recognized

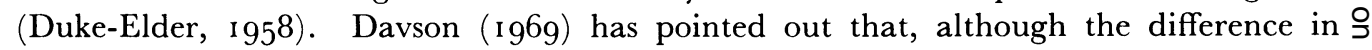
osmolality between the aqueous humour and the eye contributes to the intraocular pressure, $\vec{\nabla}$ considerable changes in osmolality and flow into the eye will be accompanied by relatively small changes in intraocular pressure. Moreover, previous studies (Hempel, I964; 岇 Iverson and Brown, I967) have demonstrated no direct relation between physiological $\vec{\bullet}$ serum osmolar variation and intraocular pressure. Hempel suggested that intraocular pressure and serum osmolar variations were due to an underlying adrenocortical rhythm, a "biological time clock". It is, however, well established that osmotically active agents alter intraocular pressure when given for experimental, diagnostic, or therapeutic purposes (Davson and Thomassen, 1950; Galin, Aizawa, and McLean, I959, I961a). These are acute changes and are associated with unphysiological fluctuations in serum osmolality (Galin and others, I96ra). A priori it would seem that any osmotic change would have some effect on intraocular pressure unless masked by homeostatic mechanisms or by pathological variations in aqueous production or outflow in the eye. Galin and others ( $19^{6} \mathrm{Ib}$ ) have called the glaucomatous eye a "sensitive osmometer", but previous studies suggest that it is too insensitive to reflect the slow and slight changes of the diurnal pattern.

The present study is another investigation into the relationship between normal diurnal osmolality changes and intraocular pressure.

\section{Material and methods}

A population consisting of persons with glaucoma or "ocular hypertension" or "normal" eyes was studied. In all the seven glaucoma cases the discs were cupped and the intraocular pressures quite $N$ abnormal and the fields showed glaucomatous loss or at least contraction (see Table I). The N glaucoma cases were all taken off treatment well before the study or had never been on treatment. N Four of the five cases of ocular hypertension had normal discs and normal fields but the fifth patient $\frac{\omega}{\sigma}$ was found to have early glaucoma field loss when examined about 2 years after the osmolality study (see Table I). The seven "normal" cases had normal discs and low normal pressures. Field examinations were not performed in the normal group.

Applanation tonometry with withdrawal of a venous blood sample shortly after tonometry was 0 done at a roughly equal (usually 2-hourly) intervals from about 9.30 a.m. to $3.30 \mathrm{p} . \mathrm{m}$. in each case. No restriction was placed on diet or activity and a number of the persons were out-patients. $\stackrel{D}{\mathbb{D}}$ Applanation tonometry and osmolar determinations using a Fiske osmometer were performed as $\underset{\Omega}{\mathbb{Q}}$ part of the daily routine by technicians who were unaware of the nature of the study. 
Table I Findings in nineteen subjects

\begin{tabular}{|c|c|c|c|c|}
\hline \multirow{2}{*}{$\begin{array}{l}\text { Group } \\
\text { Glaucoma }\end{array}$} & \multirow{2}{*}{$\begin{array}{l}\text { Case } \\
\text { no. }\end{array}$} & \multirow{2}{*}{$\begin{array}{l}\text { Age } \\
\frac{(y r s)}{36}\end{array}$} & \multicolumn{2}{|l|}{ Diagnostic features } \\
\hline & & & \multirow[t]{2}{*}{$\begin{array}{l}\text { Glaucoma discs } \\
\text { Pathological pressures }\end{array}$} & $\begin{array}{l}\text { Field complicated by retinitis } \\
\text { pigmentosa }\end{array}$ \\
\hline & $\begin{array}{l}2 \\
3 \\
4 \\
5 \\
6 \\
7\end{array}$ & $\begin{array}{l}66 \\
61 \\
71 \\
59 \\
63 \\
63\end{array}$ & & Glaucomatous field loss \\
\hline \multirow{3}{*}{$\begin{array}{l}\text { Ocular } \\
\text { hypertension }\end{array}$} & 8 & $5^{1}$ & \multirow{3}{*}{$\begin{array}{l}\text { Normal discs } \\
\text { Raised pressure }\end{array}$} & No glaucomatous field change \\
\hline & 9 & 54 & & Late field change \\
\hline & $\begin{array}{l}10 \\
11 \\
12 *\end{array}$ & $\begin{array}{l}63 \\
46 \\
62\end{array}$ & & Normal fields \\
\hline Normal & $\begin{array}{l}13 \\
14 \\
15 \\
16 \\
17 \\
18 \\
19\end{array}$ & $\begin{array}{l}56 \\
68 \\
56 \\
68 \\
64 \\
64 \\
49\end{array}$ & \multicolumn{2}{|c|}{$\begin{array}{l}\text { Normal fundi } \\
\text { Low normal intraocular pressure }\end{array}$} \\
\hline
\end{tabular}

*Unreliable witness

A regression analysis was then performed on the data. It was implicit that the intraocular pressure points were not necessarily assumed to have a normal distribution. To facilitate the analysis pressure readings in right and left eyes for each osmolality value were averaged and the analysis was performed on these mean values.

\section{Results (Table II)}

There were no significant differences between the slopes of the regressions of pressure on osmolality either between individuals, between different groups, or between sets of readings between individuals within groups.

Table II Results

\begin{tabular}{|c|c|c|c|}
\hline Regression analysis & \multicolumn{2}{|l|}{ Regression coefficient } & Significance \\
\hline Between groups & \multicolumn{2}{|l|}{$0 \cdot 390$} & Not significant \\
\hline $\begin{array}{l}\text { Between individuals } \\
\text { within groups }\end{array}$ & \multicolumn{2}{|l|}{0.205} & Not significant \\
\hline $\begin{array}{l}\text { Between readings } \\
\text { within individuals }\end{array}$ & $\begin{array}{l}\text { (a) Glaucoma } \\
\text { (b) Ocular hypertension } \\
\text { (c) Normal }\end{array}$ & $\begin{array}{l}-0 \cdot 328 \\
-0.512 \\
-0.043\end{array}$ & $\begin{array}{l}\text { Significant at } 5 \text { per cent. level } \\
\text { Significant at I per cent. level } \\
\text { Not significant }\end{array}$ \\
\hline
\end{tabular}

On the other hand, within diseased eyes or within "hypertensive" eyes there is a statistically significant inverse relationship between intraocular pressure and osmolality and this relationship is especially evident within the hypertensive eyes. 
There were highly significant $(P<0 \cdot I$ per cent.) differences between individuals within groups with regard to their osmolality. Mean group osmolality values were: Normal, 291 ; Glaucoma, 293; Hypertension, 298.

The osmolality value for the hypertension group is highly significantly different ( $\mathrm{P}<0 \cdot 1$ per cent.) from the values for the other two groups which are not significantly different from one another.

\section{Discussion}

These data confirm the absence of any significant overall relationship between osmolality and pressure already noted by Hempel (1964) and Iverson and Brown (1967). Further $\omega_{\sigma}^{\omega}$ analysis, however, shows that within abnormal eyes there is a general tendency for there $\frac{\partial}{0}$. to be a negative relation between osmolality and intraocular pressure but the pressure in "response" to osmolar fluctuations is individual and one cannot predict that a high or low osmolality reading in different individuals will reflect any particular difference in their fु intraocular pressures either within or between groups. Osmolar values vary significantly between and within groups and it is tempting to think that the higher osmolar values in the hypertension group are reflected in the closer relationship between osmolality and $\gg$ pressure within the individuals of this group. The author is, however, quite uncertain $\stackrel{0}{C}$ why the mean osmolality is different in this group. Teleologically it seems most unlikely to be a response to pressure elevation in the eye.

The absence of any apparent relationship between serum osmolality and intraocular. pressure in "normal" eyes is to be expected as the outflow facility and secretion rate will vary to produce the desired homeostatis should there be a serum osmolar change.

\section{Summary}

The relationship between serum osmolality and intraocular pressure was investigated in persons with "normal" eyes and in subjects with chronic glaucoma and in subjects with "ocular hypertension". Regression analysis of the data showed that there was no relationship present in normal eyes but that in both ocular hypertension and glaucoma individuals응 showed a significant inverse relationship between osmolality and pressure, although the response was idiosyncratic and there was no overall group or between-group relationship between the parameters.

The author gratefully acknowledges the help received from Dr. Antonovics of Stirling University who most kindly undertook a large part of the statistical analysis of the data. He wishes to thank Dr. C. R. S. O Jackson and Dr. J. Hughes for the facility of making this study on patients under their care.

\section{References}

DAvson, H. (I969) “The Eye", 2nd ed., vol. I, p. 220. Academic Press, New York and London - and Thomassen, T. L. (1950) Brit. F. Ophthal., 34, 355

DUKE-ELDER, S. (1958) "System of Ophthalmology", vol. I, p. 14. Kimpton, London

galin, M. A., aizawa, f., and malean, J. м. (i959) A.M.A. Arch. Ophthal., 62, 347

$\longrightarrow, \longrightarrow$ (1961 a) $\begin{aligned} & \text { Amer. J. Ophthal., 52, I } 5 \\ & (\text { (196I b) }\end{aligned}$

HEMPEL, A. C. A. (1964) Exp. Eye Res., 3, 85

IVERSON, D. G., and BROWN, D. W. (I967) Ibid., 6, I 79 